\title{
Lost in transition? Sexuality and justice in post-conflict Northern Ireland
}

\author{
Marian DugGan ${ }^{1}$
}

Kent University

\begin{abstract}
Northern Ireland has pioneered the delivery of transitional justice, largely as a result of its troubled past. Efforts to guide this long-divided society towards greater inclusion have been facilitated by a range of processes (judicial and otherwise) designed to deliver truth, justice and accountability. Legal requirements to consider a broader demographical representation in consultations means that lesbian, gay, bisexual and transgender voices are increasingly evident in this transition. Yet continued political resistance to sexual minority equality, set against a backdrop of wider social integration, indicates the piecemeal approach to progress which is being adopted. This article critically analyses the socio-legal positioning of sexual minorities in Northern Ireland's ongoing processes of transitional justice. In addressing how sexual orientation fits with the driving factors underpinning a move towards a 'post-conflict' society, the analysis queries the heteronormative cultural dynamics informing this utopian future and the impact this may have on exacerbating rather than eradicating homophobic victimisation.
\end{abstract}

Key words: Northern Ireland; sexual minorities; transitional justice; marginalisation; homophobia.

\section{Introduction}

Gor much of the latter half of the twentieth century (1968-1998), social and political life - in Northern Ireland was dominated by the often violent ethno-political conflict known as the 'Troubles'. This conflict segregated citizens along sectarian lines whereby being Protestant or Catholic, Unionist or Nationalist, or British or Irish dominated identity politics. The worst of the sustained violence abated with the signing of the Good Friday Agreement (GFA) 1998, which underpinned a commitment to move towards a more holistic, peaceful society. Processes of conflict transformation (judicial and otherwise) in Northern Ireland have involved learning lessons from the past in order to deliver truth, justice, accountability and peace to an increasingly inclusive, integrated and equal society. Therefore, while the legacy of the Troubles continues to inform contemporary sociopolitical life in Northern Ireland, it also renders the region particularly suited to the development and delivery of transitional justice mechanisms.

1 I wish to express gratitude and thanks to Sinéad Ring and the anonymous reviewer for their helpful comments on earlier drafts of this paper. Any errors or oversights are mine alone. 
Human rights legislation has been integral to this journey, ensuring that parity, fairness and rights have been addressed beyond the identities outlined above. The social and political focus on sectarian tensions during (and since) the Troubles shielded from view many other forms of prejudice, inequality and victimisation. Over the past two decades, gradual efforts to address violence and discrimination outside of this sectarian paradigm have improved, with emerging research and theory into identity-based victimisation demonstrating the need to consider the impact of Northern Ireland's socio-cultural history more broadly, particularly in relation to the impact on homophobia. ${ }^{2}$ The importance of invoking a culturally specific approach to ensure sexual minority rights and citizenship was first noted during the struggle for homosexual decriminalisation in Northern Ireland. The fact that this occurred in 1982 (15 years after England and Wales), and only as a result of intervention by the European Court of Human Rights, is indicative of the additional challenges and barriers to effecting sexual minority equality. More recent Northern Ireland-specific examples of these barriers include the legal struggles concerning the lifetime ban on gay male blood donations, access to equal (same-sex) marriage and securing adoption rights for civil partners. This geographical discrimination against members of lesbian, gay, bisexual and trans* (LGB\&T) communities in Northern Ireland shows the need to view LGB\&T rights as human rights which are deserving of recognition within and beyond the context in which they are set.

Herein lies a political paradox: resistance to LGB\&T equality in Northern Ireland is set against a backdrop of rhetoric advocating for greater 'cohesion, sharing and integration'. Embedded in this rhetoric has been reference to Northern Ireland's engagement in restorative and transitional justice mechanisms; these are mostly alternative justice processes characterised as being community focused. However, while these modes of justice may offer LGB\&T communities in Northern Ireland the potential for inclusion, reparation and recognition, LGB\&T-specific analyses remain largely absent in mainstream conflict transformation literature generally, and in Northern Ireland specifically. This article explores the complexity of this political paradox and its impact on excluding LGB\&T communities in Northern Ireland from conflict transformation processes. In doing so, it offers a culturally specific, critical analysis of sexual minorities' socio-legal positioning before juxtaposing this with the aims and values of transitional justice discourses, strategies and mechanisms. The discussion draws on the social and statutory difficulties faced by LGB\&T communities which demonstrate a need for redress yet remain absent from mainstream analyses of justice. In particular, an exploration of the heteronormative cultural dynamics informing the move to a post-conflict society questions the impact this may be having on exacerbating rather than eradicating homophobic sentiment and victimisation in Northern Ireland. The article concludes with the recommendation that 'queering' transitional justice is an approach which can, and should, be adopted for the benefit of all.

\section{Examining Northern Ireland's 'politics of the past'}

Northern Ireland is routinely described as a society where 'the present is in the past', a factor which continues to shape the specific dynamics of its transition towards peace. For much of the previous century, Northern Ireland has been characterised as a deeply divided society. Established politically in 1920 from the six most north-eastern counties in the island of Ireland, Northern Ireland's approximate population of 1.85 million

2 See M Duggan, Queering Conflict: Examining Lesbian and Gay Experiences of Homophobia in Northern Ireland (Ashgate 2012); J Curtis, 'Pride and Prejudice: Gay Rights and Religious Moderation in Belfast' (2013) 61 Sociological Review 141. 
people remains largely comprised of Protestant Unionists and Catholic Nationalists. ${ }^{3}$ Sectarian tensions between these two communities are based on historic political, religious and national divisions rooted in the British colonisation of Ireland which still informs many modern-day community events. ${ }^{4}$ Unionist communities derive from the sixteenth-century Protestant English and Scottish settlers; many still consider themselves British and wish to retain or enhance Northern Ireland's links to the UK. Nationalists, on the other hand, largely derive from the native Catholic Irish population; they consider themselves Irish and some seek reunification of the island of Ireland as a singular ethnopolitical entity. In recent years, however, a growing minority of people have chosen to identify as 'Northern Irish', indicating the changing dynamics of inclusivity in identity, positionality and subjectivity among emerging generations. ${ }^{5}$

The underlying tensions between communities were not just limited to ethno-national identity differences, but the discrimination arising from the unequal economic, social and political opportunities negatively impacting on Catholics. As civil rights movements began to take hold in the 1960s, these ideologies influenced Catholics to organise and mobilise against Unionist political control, most notably in housing and employment discrimination. Between 1968 and 1998, the fluctuating violence between Republican and Loyalist paramilitaries and the British Army claimed the lives of approximately 3500 people. ${ }^{6}$ The $\mathrm{GFA}^{7}$ in 1998 signalled a new chapter and a commitment to peace based on consociationalist politics. ${ }^{8}$ Although the Democratic Unionist Party (DUP) was not a signatory to this agreement (and remain opposed to it), a devolved administration (the Northern Ireland Assembly) was formed with the remaining political parties who were signatories to the GFA. 9 'This political arrangement sought to ensure governmental balance, redressing Northern Ireland's legacy of Unionist administrative domination and the exclusion of Nationalist representation. Nonetheless, the liberal, democratic approach set out in the GFA stipulates that the power-sharing administration requires representation from both cross-community parties as well as non-sectarian 'Others'. ${ }^{10}$ Ensuring political recognition beyond the traditional binary is vital; as Campbell and Ní Aoláin illustrate, the intensive focus on a dyadic interaction between traditionally opposed political (and social) groups which foregrounds the involvement of existing political elites from represented parties may be detrimental to others seeking to infiltrate this insular domain. ${ }^{11}$

3 Northern Ireland Statistics and Research Agency, 'Northern Ireland Census: Key Statistics Summary Report 2014' (Stationery Office/Official Publications 2014) 46 <www.nisra.gov.uk/sites/nisra.gov.uk/files/ publications/2011-census-results-key-statistics-summary-report.pdf $>$.

4 See M Duggan, 'Sectarianism and Hate Crime in Northern Ireland' in N Hall, A Corb, P Giannasi and J Grieve (eds), The International Handbook on Hate Crime (Routledge 2014) 117.

5 Northern Ireland Statistics and Research Agency (n 3) 46.

6 P Dixon, Northern Ireland: The Politics of War and Peace (Palgrave Macmillan 2001).

7 This is also known as the 'Belfast Agreement'.

8 J McGarry and B O’Leary, The Northern Ireland Conflict: Consociational Engagements (Oxford University Press 2004).

9 Signatories to the agreement were the Ulster Unionist Party, Sinn Féin, Social Democrat and Labour Party, Alliance Party, Progressive Unionist Party, the Northern Ireland Women's Coalition and Labour.

10 As an indication of how heavily informed by the dominant sectarian ethno-national identity divide the political landscape is, all political candidates and parties - regardless of their adherence or otherwise to a 'sectarian' identity - must demarcate themselves as 'Nationalist', 'Unionist' or 'Other' upon entering Northern Irish politics.

11 C Campbell and F Ní Aoláin, 'Local Meets Global: Transitional Justice in Northern Ireland (2002) 26(4) Fordham International Law Journal 871-92. 


\section{Transitional justice in Northern Ireland}

The social and political transition of a society towards a post-conflict status does not in itself indicate the presence of transitional justice. Instead, it is the underlying collective desire to match the desistance of violence with efforts to build a more cohesive, interactive and progressive society which demonstrates the fundamental tenets of transitional modes of justice. ${ }^{12}$ Ensuring that the mistakes of the past are not replicated in the future when creating spaces to engage with trauma involves a holistic, longitudinal approach to transformation as opposed to implementing short-term change. Effectively addressing (and redressing) legacies of trauma, harm and human rights abuses in a meaningful and lasting way requires that these practices offer alternatives to existing justice mechanisms. This may be seen as contrasting traditionally masculinist, patriarchal and heteronormative 'justice' structures which informed the initial conflict environment. Unlike traditional justice measures, transitional approaches do not necessarily prioritise (retributive) criminal sanctions, but rather indicate the need to include a wider range of perspectives, approaches and stakeholders in reparative processes. ${ }^{13}$ The production of international guidelines has aided countries' efforts towards democracy, legitimacy and peace while ensuring compliance with the rule of law in transitioning societies. ${ }^{14}$ The variety of judicial and non-judicial measures available include criminal prosecutions, reparation programmes and institutional reforms, with truth commissions being by far the most popular type of transitional justice process. ${ }^{15}$

Discussions around truth commissions arose following the Report of the Consultative Group on the Past ${ }^{16}$ which began a process of deliberation concerning how Northern Ireland's Troubled past should be addressed. A key issue of concern was policing, particularly the Royal Ulster Constabulary (RUC) which had been established in 1922 following the partition of Ireland. ${ }^{17}$ In addition to its regular policing duties, maintaining the partition was one of the key tasks attributed to the early RUC. The organisation was comprised predominantly of officers from a Protestant background and claims of bias regarding its interactions with Catholics soon led to several clashes as a result of unfair policing practices, particularly concerning the partisan enforcement of legislation which had expanded the RUC's powers of arrest, questioning and detention. ${ }^{18}$ The 'us and them' approach heightened during the Troubles period, with many feeling powerless to challenge, resist or report unfair policing practices. The report highlighted the contentious relationship between the RUC and the communities it policed and the fact that attitudes were polarised with respect to whether or not a formal truth recovery process should take place. Although one aim of transitional justice is to address opposing or polarised viewpoints by way of inclusion and recognition of different experience as valid, Lawther has indicated that Unionist resistance to the report's suggestion of a formal truth recovery process demonstrates a position which is in line with a broader

12 P Lundy and M McGovern 'Whose Justice? Rethinking Transitional Justice from the Bottom Up' (2008) 35(2) Journal of Law and Society 265-92.

13 R Teitel, Transitional Justice (Oxford University Press 2000).

14 Office of the United Nations High Commissioner for Human Rights (OHCHR) 'Rule-of-Law Tools for Postconflict States' (OHCHR 2006) <www.ohchr.org/Documents/Publications/RuleoflawVettingen.pdf>.

15 Lundy and McGovern (n 12).

16 Consultative Group on the Past, 'Report of the Consultative Group on the Past' (CAIN 2009) http://cain.ulst.ac.uk/victims/docs/consultative_group/cgp_230109_report.pdf.

17 It remained known as such until 2001, whereupon it was renamed the Police Service of Northern Ireland as part of the swathe of reforms set out in the GFA.

18 K Boyle, T Hadden, and P Hillyard, Ten Years On in Northern Ireland: The Legal Control of Political Violence (Cobden Trust 1980). 
Unionist disillusionment with various elements of the peace agreement. ${ }^{19}$ Opposition is mainly founded on fears that Republicans would use the opportunity to 'revise history' and advance an agenda of political and cultural domination. Former members of the RUC also opposed the Ombudsman's suggestion due to personal perceptions that the British state sought to render the policing organisation in some way culpable for the conflict. ${ }^{20}$ However, it is largely as a result of several contentious 'policing' issues that Northern Ireland is one of the key sites for transitional and restorative justice developments in modern society. Examples of two long-standing, community-based restorative justice projects are the Community Restorative Justice Ireland (which is Republican focused) and Northern Ireland Alternatives (which is Loyalist focused). ${ }^{21}$ Both of these projects arose from the GFA and were designed to provide non-violent alternatives to traditional, informal punishment practices. ${ }^{22}$ The projects are led by political ex-prisoners and former combatants from the key paramilitary groups who were active during the Troubles. The success of the projects can be traced to their operating outside of the scope of the traditional criminal justice system and its clearly defined victim/offender dichotomy, as well as seeking to address underlying causes of people's offending generally, rather than in relation to the conflict specifically. ${ }^{23}$

While a core transitional justice mechanism remains absent in Northern Ireland, the projects proposed or already in practice illustrate a focus on communities and issues linked directly or overtly to the sectarian conflict. This may be inferred as demonstrating a 'hierarchy' of intervention based on the suffering and harm incurred, as well as the visibility of need or advocates, creating difficulties for marginalised or minority groups to have their voices, experiences and fears recognised. ${ }^{24}$ Underpinning change in both social and criminal justice domains requires a re-evaluating of processes of governance which are truly democratic, promote peace and ensure future fairness. Whereas traditional sectarian binaries may have limited the ability to adequately represent alternative identities, new mechanisms may prove more inclusive; this set of circumstances offers possible opportunities to minority groups and their advocates seeking to engage in emerging justice mechanisms. As a result, scholarly analyses of conflict transformation from gendered or feminist perspectives are becoming more established; yet explorations addressing the role of sexuality and sexual identity are less well developed by comparison. The following section analyses how the failure to include the persecution of sexual and gender minorities may possibly be indicative of the regard with which they are held in the society in question.

19 B Hayes and I McAllister, 'Protestant Disillusionment with the Northern Ireland Peace Agreement' (2004) 13(1) Irish Journal of Sociology 109; C Lawther, "'Securing" the Past: Policing and the Contest over Truth in Northern Ireland' (2010) 50 British Journal of Criminology 455.

20 Lawther (n 19) 456.

21 A Eriksson, Justice in Transition: Community Restorative Justice in Northern Ireland (Willan 2009).

22 Local paramilitary groups operated informal methods of 'community policing', often ensuring that very visual punishments were meted out to those who were considered to have contravened social norms. These punishments included tarring and feathering (often encompassing the person being shackled to a tree or lamppost with their alleged 'crime' displayed on a board around their neck), 'kneecapping' (where a person's kneecaps are shot or crushed with a heavy implement), or having their homes targeted with incendiary devices.

23 Eriksson (n 21).

24 See M Duggan and V Heap, Administrating Victimization: The Politics of Anti-Social Behaviour and Hate Crime Policy (Palgrave Macmillan 2014). 


\section{Policing sexuality in Northern Ireland}

During the height of the conflict, segregated demarcations of space and place were a fact of life for many in Northern Ireland, with people altering their social movements either according to deeply ingrained personal safety maps or as a result of imposed barriers, curfews and restrictions. Shirlow indicates how overtly visible and covertly implied means of segregation served important purposes for those in positions of power; the reproduction of ideological differences along the Unionist/Nationalist divide appeared enhanced through visible markers of spatial segregation. ${ }^{25}$ As well as determining spaces as belonging to one or other 'side' as part of these internalised safety maps, Northern Ireland's famous murals overtly marked out opposing territories in urban areas and city centres - most notably in Belfast. Many of these murals depicted notable members of the community, anonymous masked gunmen, historical events, and slogans indicating desires for unification with either Britain or Ireland. ${ }^{26}$ In addition to these spatial markers, efforts to protect Northern Ireland's commercial and economic hub included the erection of a physical enclosure known as the 'ring of steel' in Belfast city centre throughout much of the 1970s. High metal railings were placed around the central area and pedestrian access was only permissible via a dedicated entrance, where enhanced security measures meant that guardsmen searched people entering the cordon. At night, the city centre was virtually deserted as trading hours ceased and people retreated back to their homes for the evening, eager to stay off the streets, avoiding suspicion and potential danger. For most people, nightly curfews became a way of life as Northern Ireland progressed further into violent conflict and marked territorial divisions.

Paradoxically, for the growing LGB\&T community in Belfast, these security measures played a very important part in enabling greater freedom and eventually challenging (police) homophobia. Publicans and hotel owners in Belfast were economically affected by reduced trade as a result of imposed curfews, cordons and curtailed mobility. ${ }^{27}$ The small but significant community of lesbians and gay men took advantage of this opportunity; discos became popular weekly events and, although publicity was limited, they were usually well attended. These discos were seen by many LGB\&T patrons as safe havens and, for the most, part the evenings passed without any problems. Occasionally, however, members of the police and security forces would interrupt the discos in order to carry out a search of the premises and those occupying them. One venue in the heart of the city centre was subjected to repeated raids which led some attendees to deduce that such tactics were less about security and more akin to homophobic intimidation. ${ }^{28}$ For many who became used to such interruptions, this proved a small price to pay for what was otherwise a hassle-free environment away from the scrutiny of morally minded, disapproving family members, work colleagues or neighbours. For others, fears of exposure were enhanced as a result of homosexuality remaining criminalised in Northern Ireland at the time; therefore knowledge about a person's sexuality could be used as grounds for an arrest of 'gross indecency'. Men were also vulnerable to blackmail from

25 P Shirlow, 'Ethnosectarianism and the Reproduction of Fear in Belfast' (2003) 81 Capital and Class 77.

26 While many murals have been replaced with newer, less violent, images, more akin to the 'new Northern Ireland', other visibly politicized indicators remain: paving stones in predominantly Unionist areas are often painted red, white and blue to complement the many Union Jack flags flying overhead, while in Nationalist areas, Irish tricolour symbolism denotes traditional Celtic designs (ibid). 
the police who sought to use them to inform on other members of the community. ${ }^{29}$ Despite the numerous raids, actual arrests for gross indecency were rare, but the relationship between the police and members of the LGB\&T community was fundamentally strained.

In England and Wales, the Sexual Offences Act 1967 had initiated the gradual decriminalisation of homosexuality. However, staunch opposition to the British government's plans to extend the law to Northern Ireland was demonstrated by DUP leader Reverend Ian Paisley via his 'Save Ulster from sodomy' campaign. His efforts worked initially, impeding activism by LGB\&T groups to address this decriminalisation discrepancy. Eventually, it was the arrest of Northern Ireland Gay Rights Association (NIGRA) Secretary Jeffrey Dudgeon by the RUC for marijuana possession during a raid on his home which sparked change. ${ }^{30}$ The police had confiscated personal diaries which indicated Dudgeon's engagement in homosexual acts which he was interrogated about at the police station. Although he was threatened with a charge of gross indecency, the prosecution service decided not to take the case any further. NIGRA used the opportunity to advance its decriminalisation efforts on the basis of police harassment and discrimination and, led by Dudgeon, brought a case under Article 8 (the right to a private life) of the European Convention on Human Rights to the European Commission of Human Rights, which in turn referred the case to the European Court of Human Rights. In 1981, the court decided that the legal prohibition of homosexual acts between male persons over 21 years of age breached the applicant's right to respect for his private life, ordering that homosexuality be decriminalised in Northern Ireland. This was to be the first of several legal developments impacting positively on LGB\&T citizens in Northern Ireland which required implementation from outside the domestic legislative domain and the recognition of LGB\&T rights as buman rights. This allowed domestic LGB\&T activists - who continue to play significant roles in securing legal protections for gender and sexual minorities in Northern Ireland - to situate their rights struggles within a broader international framework.

Of equal importance was the continued, enhanced political agency of lesbian, gay and bisexual advocates, who demonstrated harmony across otherwise segregated identity divides as highlighted by Dudgeon shortly afterwards:

It is also very heartening that in a province where religious differences divide most of the community, the gay social scene has never been sectarian. The labels 'Protestant' and 'Catholic' do not apply: people develop relationships and friendships with each other as individuals and not as representatives of either community. This bond of a common sexuality is far stronger than adherence to sectarian differences. Heterosexual society in Ulster could well take a lesson from the homosexual minority in its midst. 31

The noteworthiness of the campaign on these grounds, however, was largely overlooked by mainstream society. Nevertheless, this is important as sectarianism is perceived to permeate the very fabric of society in Northern Ireland, with commentators suggesting

29 Incidents of entrapment continued to impede relations between gay men and the police, being cited in later research as informing why some victims refused to report their experiences of victimisation.

30 M McLoughlin, 'Crystal or Glass?: A Review of Dudgeon v United Kingdom on the Fifteenth Anniversary of the Decision’ (1996) 3(4)(Dec) Murdoch University Electronic Journal of Law $<$ www.austlii.edu.au/au/journals/MurUEJL/1996/36.html>.

31 J Dudgeon, Gay Rights in Northern Ireland: A Report (Public Records Office Northern Ireland 1980), ref no $\mathrm{D} / 3762 / 1 / 1 / 11$. 
that nothing is above or exempt from this. ${ }^{32}$ Suggestions of the absence of sectarianism as a determining, dividing or denigrating force within the LGB\&T community suggests that spaces were - and still may be - created outside of this paradigm. ${ }^{33}$ The exclusion of this aspect of identity harmony and collective organising is also largely overlooked in mainstream scholarship pertaining to Northern Ireland's Troubles, illustrating the marginalised position occupied by LGB\&T identities within this historical framework. It is through interrogating such processes of 'structural exclusion' which in turn feed into 'cultural imagining' of subordinated and minority groups which Perry suggests is vital in order to recognise the infrastructures facilitating the systemic violence faced by these groups. ${ }^{34}$ This is a key issue for cultures in transition, as Fobear has also noted:

In transitioning societies, homophobia and anti-queer violence is often ignored or placed outside of other state and local directed violences, such as in instances of ethnic or political violence. This not only ostracizes sexual and gender minorities from transitional justice processes, but allows for further violence and violations against sexual and gender minorities to be committed in post-conflict periods. ${ }^{35}$

Curtis asserts that the production and consequences of harmful discourses pertaining to homosexuality in Northern Ireland 'can only be understood within the local context of ethnopolitical conflict, and the ways that political rhetoric and practice are suffused with communal and religious understandings' ${ }^{36}$ It is this cultural imaging of LGB\&T citizens which has rendered them vulnerable, yet acceptable, targets of persecution; something which necessitates recognition and reparation, most notably in transformative cultures seeking to attain meaningful equality and progress.

\section{Homophobic victimisation: from rhetoric to reality}

'Homophobia' as a concept is generally understood as being a way of understanding the fear and hatred felt towards homosexuality or homosexuals. George Weinberg, who is credited with coining the term in the 1960 s, commented on the rationales he saw as underpinning such an emotion as being a fear that was 'associated with a fear of contagion, a fear of reducing the things one fought for - home and family. It was a religious fear and it had led to a great brutality as fear always does. ${ }^{37}$ Homophobia can range from overtly prejudicial attitudes through to discriminatory or victimising behaviour; the effects may be felt both directly and indirectly depending on the power, status and actions of the person harbouring the sentiments. Homophobic prejudice is informed by culturally specific social, religious and political views about homosexuality which suggest the need to protect morality, the family and the primacy of procreation. ${ }^{38}$ Therefore, it is a prejudice underpinned by, and reliant upon, heterosexism noted by

32 R McVeigh and B Rolston, 'From Good Friday to Good Relations: Sectarianism, Racism and the Northern Ireland State' (2007) 48 Race and Class 1.

33 Duggan (n 2) 38.

34 B Perry, 'Accounting for Hate Crime: Doing Difference" in B Perry (ed), Hate and Bias Crime: A Reader (Routledge 2003) 17.

35 K Fobear 'Queering Truth Commissions' (2013) Journal of Human Rights Practice 1, 4.

36 J Curtis, 'Pride and Prejudice: Gay Rights and Religious Moderation in Belfast'(2013) 61 Sociological Review $141,144$.

37 G Herek, 'Beyond “Homophobia”: Thinking about Sexual Stigma and Prejudice in the Twenty-first Century' (2004) 1 Sexuality Research and Social Policy 6.

38 See M Foucault, The History of Sexuality (Penguin Books 1976); G Kinsman, The Regulation of Desire: Homo and Hetero Sexualities (Black Rose Books 1996); K Plummer, Sexual Stigma: An Interactionist Account (Routledge 1975). 
Herek as constituting 'the belief system that allows homosexuality to be stigmatised, denigrated or ignored' whilst simultaneously privileging heterosexuality 'though societal customs, institutions and individuals' attitudes and behaviour'. ${ }^{39}$ While this imbalance is disadvantageous to sexual minorities, Peterson outlines the practical dangers inherent in heterosexism, namely the demonising and criminalising of sexual activities and identities. ${ }^{40}$ Therefore, attempts to address homophobia on an interpersonal basis may prove redundant if the wider socio-cultural context in which it manifests are not adequately accounted for.

Cultural and social prejudices towards homosexuality in Northern Ireland have long been informed and sustained by morally conservative religious and political discourses. Furthermore, as Hayes and Nagle highlight, homophobic prejudice and violence 'has become a common feature of societies emerging from violent and protracted conflict'. ${ }^{41}$ These discourses were illustrated in the struggle for homosexual decriminalisation outlined above, but became increasingly notable in the decade following the signing of the GFA. Several infamous, disparaging comments against homosexuality made by highprofile political elites, usually from Unionist backgrounds, obtained significant media coverage. ${ }^{42}$ The most notable of these occurred in 2008, when DUP MP Iris Robinson (and, at the time, wife of the First Minister Peter Robinson) was asked to comment on the brutal assault of a young gay man near Belfast. While doing so, she publicly stated that she felt homosexuality was an 'abomination', that it 'nauseated' her and that homosexuals could be 'cured'; furthermore, it later emerged that she had stated that she believed homosexuality and sodomy to be worse than paedophilia. ${ }^{43}$ Many in the LGB\&T community felt that Robinson's comments and the apparent impunity 44 with which they were made was offensive and victim-blaming. Furthermore, there were fears that such sentiments could potentially incite further acts of homophobic hate crime.

As Mason notes, the failure to condemn homophobia not only 'promotes an atmosphere that condones violence against gay men and lesbians', but such violence 'will only fail to serve a function for the perpetrators if the prejudicial attitudes undergirding such violence are no longer supported by societal norms or by religious, legal and political doctrines'. ${ }^{5}$ Drawing specifically on the fall-out from Robinson's comments, Ashe indicates how the assessment of speech must always be located within its social and political conditions; the intent cannot be separated from the cultural environment in which it was expressed. ${ }^{46}$ Therefore, such sentiments were illustrative of the state, struggle and stagnation of sexual politics in Northern Ireland and were instrumental in

39 G Mason, Violence Against Lesbians and Gay Men (Duncan Chappell 1993) 2.

40 V Peterson, 'Sexing Political Identities/Nationalism as Heterosexism' (1999) 1 International Journal of Feminist Politics 47.

41 B Hayes and J Nagle, 'Ethnonationalism and Attitudes Towards Gay and Lesbian Rights in Northern Ireland' (2016) 22(1) Nations and Nationalism 21.

42 Duggan (n 2) 71-2.

43 'DUP's Iris Robinson: Gays More Vile than Child Abusers' Belfast Telegraph (Belfast, 21 July 2008) <www.belfasttelegraph.co.uk/news/local-national/iris-gays-more-vile-than-child-abusers-13913517.html>; D Young, "Gay Lifestyle is "Abomination" not a Mental Disorder: Iris' Belfast Telegraph (1 July 2008) $<$ www.belfasttelegraph.co.uk/news/iris-robinson-gay-lifestyle-is-abomination-not-a-mental-disorder28785244.html>.

44 After an investigation lasting a year, the Police Service of Northern Ireland stated that no action would be taken against Robinson for these public statements as she had done nothing wrong.

45 Mason (n 39) 6.

46 F Ashe, 'Iris Robinson's Excitable Speech: Sexuality and Conflict Transformation in Northern Ireland' (2009) 29 Politics 20. 
seeking to retain this political status quo in the face of social progression. Robinson's comments indicated the depth of cross-over between some politicians' personal and professional beliefs as well as the deeper historical structural factors informing homophobia. However, they also adhered to a perspective espoused by members of her party and faith for decades and thus can be seen as in keeping with dominant ideologies in this respect. To fully understand the 'politics' behind Robinson's speech, therefore, one must scrutinise historical structures of sexual oppression and the impact of the prolonged, heteronormative, ethno-nationalist conflict on the advancement of sexual minority rights in Northern Ireland. ${ }^{47}$

The GFA has required that politicians divided along ethno-national and religious lines tolerate one another in order to ensure the future of the Northern Ireland Administration. Disparaging or incendiary comments made about sexual minorities may contravene and undermine anti-discrimination laws, but they are not going to undermine the ongoing peace process per se. The recognition of this has led some to suggest that politicians' apparent impunity when making public homophobic statements mirrors a shift in cultural practice whereby targeted victimisation has migrated from sectarianism to homophobia. ${ }^{48}$ This, in part, may be down to the transitional nature of Northern Irish society; focusing transitional justice mechanisms on abating the primary or prioritised tensions underpinning the conflict may have negative implications for vulnerable and/or minority communities as a result of violence being deflected as opposed to reduced or eradicated. These sentiments were first proposed by Knox in his analysis of the violent regulation enforced by paramilitary policing within communities. ${ }^{49}$ He questioned the state's complicity in turning a 'blind eye' to some forms of violence in order to ensure the continuance of an 'imperfect peace', suggesting that 'this raises the wider question as to whether paramilitary violence, the by-product of a negotiated political settlement in Northern Ireland, would be tolerated as a "price worth paying" in other areas of domestic, homophobic or racist violence'. ${ }^{50}$ In other words, the primacy afforded to quelling cross-community tensions may have negative implications for other vulnerable groups with comparably less socio-political representation.

Paramilitary condemnation of 'immoral' behaviours - one of which homosexuality is considered by some to be - has been recognised as a valid cause for concern in Northern Ireland, ${ }^{51}$ particularly due to the subtlety with which this form of 'policing' can take:

Sexual dissidence had been seen by certain organizations, operating within some localities, to represent anti-social activity. Those who have been rumoured, or proven to be gay . . . have come under pressure to leave tightly knit, local communities, and in many cases forcibly evicted. ${ }^{52}$

Drawing on similar sentiments to Knox, findings from the Institute for Conflict Research's study into lesbian and gay experiences of homophobic violence described such

47 Ibid 20, 22.

48 R O'Leary, 'Christians and Gays in Northern Ireland: How the Ethno-religious Context Has Shaped Christian Anti-gay and Pro-gay Activism' in S Hunt (ed), Contemporary Christianity and LGBT Sexualities (Ashgate 2009); see also Duggan (n 2) 25-45.

49 C Knox “'See No Evil, Hear No Evil”: Insidious Paramilitary Violence in Northern Ireland' (2002) 42 British Journal of Criminology 164.

50 Ibid 164, 181.

51 R Kitchin and K Lysaght, 'Heterosexism and the Geographies of Everyday Life in Belfast, Northern Ireland' (2003) 35 Environment and Planning A 489; N Jarman and A Tennant, An Acceptable Prejudice? Homophobic Violence and Harassment in Northern Ireland (Institute for Conflict Research 2003).

52 R Kitchin, 'Sexing the City: The Sexual Production of Non-heterosexual Space in Belfast, Manchester and San Francisco’ (2002) 6 City 215. 
victimisation as one of the last 'acceptable prejudices' in Northern Ireland. ${ }^{53}$ High levels of fear and (often repeated) victimisation were demonstrated among respondents which had fostered a base level of tolerance that homophobia was a 'fact of life and something to be put up with'. ${ }^{54}$ Some also noted 'a greater use of violence and a greater propensity to use violence in such attacks'. ${ }^{55}$ In almost half the incidents the perpetrator was a person known to the victim, yet a great reluctance to inform the police was demonstrated by victims. ${ }^{56}$ These issues were also highlighted by representatives of LGB\&T groups who focused on an apparent increase in frequency and ferocity of attacks, particularly on gay men, which necessitated a stronger legal response. ${ }^{57}$

Legislation pertaining to sexual orientation hate crime had not been implemented at the time of the survey, but was in place soon after via the Criminal Justice (Northern Ireland) (No 2) Order 2004, SI 1991/2002. However, confidence in the police was so low that such legislation had little effect for the first few years. Mere legal change was evidently not enough; the fact that it was homosexuality, rather than homophobia, which constituted moral reprehension had a strong symbolic and regulatory impact across society. In Radford's research, ${ }^{58}$ some of the respondents felt that members of their community would be more willing to understand (and perhaps condone) the victimisation or violence they suffered for being homosexual, regardless of the fact that they had done nothing to deserve this 'punishment' in the first place. This indicates another form of deflection, whereby the blame is situated with the victim as a result of the hierarchical status of the condemner. In sum, political rhetoric and highlighted incidents of public and paramilitary victimisation, coupled with the criminal justice system's apparent failure to adequately address homophobia, meant many LGB\&T citizens living in Northern Ireland had little faith in formal mechanisms of legal protection or redress. ${ }^{59}$

The fear, threat or incidence of homophobic violence not only regulates sexuality and sexual expression, it also has a significant impact on perceptions and behaviours; more so, perhaps, than the actual experience of crime. Perry and Alvi ${ }^{60}$ call this the 'in terrorem' effect of hate crime. The LGB\&T population in Northern Ireland is small; therefore knowledge of victimisation may spread quickly and can have indirectly negative impacts. ${ }^{61}$ Studies into the mental and physical health of LGB\&T people living in Northern Ireland have demonstrated significant discrepancies between the LGB\&T community and the general Northern Ireland population with respect to smoking, alcohol consumption, drug use, self-harm and suicide ideation. ${ }^{62}$ Alcohol consumption in the

53 Jarman and Tennant (n 51).

54 Ibid 58.

55 Ibid 65.

56 Ibid 29.

57 'Gay Men Targeted in Attacks' BBC News (19 May 2004) http://news.bbc.co.uk/1/hi/ northern_ireland/3728345.stm.

58 K Radford, J Betts and M Ostermeyer, Policing, Accountability and the Lesbian, Gay and Bisexual Community in Northern Ireland (Institute for Conflict Research 2006).

59 Kitchin (n 52) 215; see also Duggan (n 2).

60 B Perry and S Alvi, “We Are All Vulnerable”: The in Terrorem Effects of Hate Crimes' (2012) 18 International Review of Victimology 57.

61 P Iganski, Hate Crime and the City (Policy Press 2008).

62 H McNamee, Out on Your Own: An Examination of the Mental Health of Young Same Sex Attracted Men (Rainbow Project 2006); E Rooney, All Partied Out? Substance Use in Northern Ireland's Lesbian, Gay, Bisexual and Transgender Community (Rainbow Project/Public Health Agency 2012). This research comprised an internet survey of 941 LGB\&T people (319 of whom were women and 40 of whom identified as trans*) and qualitative research undertaken with 37 participants. 
LGB\&T community was noted as greater in volume and frequency than the general population, as was the smoking of cigarettes and the use of drugs; LGB\&T people were nearly three times as likely as the general population to have taken an illegal drug at some point in their lifetime. ${ }^{63}$ However, perhaps contrary to perception, anti-depressants, sedatives, opiates and cannabis consumed at home predominate consumption. Importantly, in each survey, respondents noted that the difficulty in coming to terms with their sexual orientation as a result of the negativity affiliated to it in their wider environment was a contributing factor in their consumption rates, with drugs and alcohol cited as a risky but effective way of 'escaping' this reality. ${ }^{64}$

While processes of transitioning to a truly inclusive society must recognise these 'hidden harms' and go further in efforts to protect sexual minorities' access to equality, rights and citizenship, the potentially negative and stymieing impact of unrepresentative and unsupported political power must also be rendered accountable. Breen et al indicate this in their comparison with the transitional nature of South Africa:

While political attention in both countries is generally on hate crimes that affect the majority - sectarianism in Northern Ireland and racism in South Africa deliberate and sustained efforts to tackle other forms of hate crime are critical in transitional societies, if the legacy of the past is to be fully addressed. ${ }^{65}$

One such way to effect positive change is through adherence to established human rights frameworks; in the case of Northern Ireland, this engagement with external legislatures has been vital, as the following section will indicate.

\section{Politicising sexual equality and justice}

The effective recognition and tackling of sexual minority discrimination in Northern Ireland has relied heavily upon a rights-based rhetoric informing such strategies. ${ }^{66}$ This has been further boosted by the UN Human Rights Council narrowly voting to affirm LGB\&T rights as human rights for the first time in 2011, subsequently producing its first report outlining LGB\&T rights. ${ }^{67}$ However, despite a focus on human rights violations, as noted above, the predominance of domestic sectarian issues has impeded a full understanding of violence against sexual minorities. Campaigners have had to work additionally hard to seek parity with some of the gains made elsewhere in the UK with respect to securing rights and recognising vulnerabilities. These include undergoing judicial review process to secure adoption rights for civil partners, challenging the lifetime ban on gay male blood donations, repeated calls for access to equal (same-sex) marriage rights and seeking to have transphobia recognised in law as a hate crime for the purposes of enhanced sentencing. These issues - contested by political elites - demonstrate a form of identity regulation which Fobear ${ }^{68}$ links to broader mechanisms of control, as 'homophobia and transphobia are consistently tied to nationalist, racist/ethnic, political, and militarist agendas in which the population is managed through violent control of

63 Rooney (n 62).

64 Ibid 13.

65 D Breen, I Lynch, J Nel and I Matthews, 'Hate Crime in Transitional Societies: The Case of South Africa' in Hall et al (n 4) 129.

66 L Glennon, 'Strategizing for the Future through the Civil Partnerships Act' (2006) 33 Journal of Law and Society 244.

67 UN Human Rights Council, Report of the United Nations High Commissioner for Human Rights on Discriminatory Laws and Practices and Acts of Violence Against Individuals Based on their Sexual Orientation and Gender Identity (17 November 2011) <www.refworld.org/docid/4ef092022.html>.

68 Fobear (n 35) 1, 4. 
reproduction and sexuality'. Applying this framework of analysis to LGB\&T equality in Northern Ireland highlights the culturally specific impact of political homophobia which continues to impede transformative change for LGB\&T citizens.

Nonetheless, the process of conflict transformation in Northern Ireland has boosted visibility about issues of LGB\&T sexual equality. The appropriation of new legal and political frameworks by LGB\&T groups came as a result of the opportunities offered through several pieces of legislation emerging from the GFA 1998, specifically s 75 of the Northern Ireland Act 1998. This directed public authorities to ensure appropriate LGB\&T training was available; monitor sexual orientation; consult with specialist LGB\&T organisations where relevant; and undertake equality impact assessments in order to provide the required reports on how equality directives were being operationalised. It also led to the establishment of the Northern Ireland Human Rights Commission (NIHRC), a statutory body tasked with ensuring the full and firm protection of the fundamental rights and freedoms as contained in the European Convention on Human Rights and later Human Rights Act $1998 .{ }^{69}$ Coupled with the role of the Equality Commission for Northern Ireland, these measures mean that LGB\&T individuals now have far greater powers to challenge laws in the UK courts if they believe their rights have been breached by a public authority. This is important as a defining feature of legislative developments accrued thus far and a key concern for some working in the LGB\&T sector is the impact of having these laws passed during periods of political instability, thus via direct rule from Westminster and not domestically by the Northern Ireland Assembly. Direct rule, which occurs as a result of the dissolution of the domestic government, relates to tensions between the dominant political parties which have resulted in the Assembly twice being suspended for a period of longer than 24 hours in the first seven years: first for almost four months (11 February-30 May 2000) and again for almost fourand-a-half years (14 October 2002-7 May 2007). ${ }^{70}$ It was during these periods that significant LGB\&T legislative protections and rights in Northern Ireland - such as the recognition of hate crime and civil partnerships - were bestowed by the British government, which administrated on behalf of the Northern Ireland Assembly. ${ }^{71}$ Although these changes were not subsequently repealed once the period of direct rule ceased, it is notable that they were not initiated or implemented domestically outside of these timeframes.

The impact of obstructive domestic politics on LGB\&T socio-political inclusion has been demonstrated most recently in marriage debates. Northern Ireland remains the last region in the UK where equal access to civil marriage is denied to LGB\&T couples. This anomaly is further compounded as a result of the Republic of Ireland instigating such changes following a historic public vote in favour of the law. The Northern Ireland Assembly debated and rejected proposals calling for the introduction of civil marriage equality four times before finally voting in favour by a narrow majority in November

69 C Harvey, 'Human Rights and Equality in Northern Ireland' (2006) 57 Northern Ireland Legal Quarterly 215.

70 At the time of writing (spring 2017), the Assembly is currently dissolved as a result of Deputy First Minister Martin McGuinness's resignation in the wake of the controversy surrounding the renewable heat incentive. This triggered an election as Sinn Féin refused to nominate a replacement Deputy First Minister.

71 These also include the Employment Equality (Sexual Orientation) Regulations (Northern Ireland) 2003, SI 497/2003, and the Criminal Justice (No 2) (Northern Ireland) Order 2004 which outlines increased penalties for offences motivated by hostility towards a person's sexual orientation (as well as race, religion and disability), addressing the growing levels of 'hate crime' experienced by lesbians and gay men. 
2015. However, the motion was vetoed as a result of a petition of concern ${ }^{72}$ being tabled, meaning that the motion would require a certain level of cross-community support from both Unionists and Nationalists to succeed. In other words: because the DUP is opposed to equal marriage, it will continue to veto it whilst the decision remains a domestic one with the Northern Ireland Assembly. This is an example of how, in societies such as Northern Ireland, the political domination of one group can lead to the personal and professional (or personal and political) becoming indistinguishable to the point where justice processes are used to further personal prejudices. ${ }^{73}$

A petition of over 20,000 signatures was presented to Stormont as part of public protests against the DUP following the most recent marriage veto. Some advocates have suggested that a referendum be held on this issue, much like the vote which secured equal marriage rights in the Republic of Ireland. Some LGB\&T advocates have demonstrated resistance to proposals for a referendum as campaigning may prove prohibitively costly and resource-intensive for the already stretched organisations working to represent and support LGB\&T citizens in Northern Ireland. Also, while seeking fundamental human rights through the available legal channels ensures that homophobic political elites are forced to account for their prejudice in a public forum, it also exposes LGB\&T communities to vile rhetoric, as witnessed during the Irish referendum. Research into the impact of the 'No' campaign on LGBTI ${ }^{74}$ citizens in the Republic demonstrated the elevated levels of psychological distress incurred as a result of the negative language used about LGBTI communities in advertisements and discussions. ${ }^{75}$ Many respondents indicated that they would not want to go through a referendum again as they had been left feeling anxious, distressed and in some cases suicidal. ${ }^{76}$ Fears that similar negative outcomes, coupled with the potential for the issue to be hijacked by sectarian concerns ${ }^{77}$ and the fact that questions of fundamental human rights should not be decided by a popular vote, have all informed Northern Irish LGB\&T advocates to resist a similar campaign in the north. ${ }^{78}$

Writing in advance of the current marriage debates, Ashe described an awareness around 'the need for politics and debate, not simply legal change' in relation to LGB\&T

72 The GFA included several legal tools designed to ensure that a fair and representative government would ensue wherever possible. One such tool is the 'petition of concern'; this allows a Member of the Legislative Assembly (MLA) to effectively veto any motion proposed by another MLA if they believe the motion to be harmful to the ongoing peace process. However, these current arrangements, which are designed to ensure that political decision-making and related policy implementations are fair, equal and representative, may, in some cases, serve to enhance the dominance of Unionist parties' socio-political positioning. The powersharing agreement outline a need to account for both perspectives, yet it is often the will of the Unionist parties which dominates decisions, particularly when it is a Unionist MLA who invokes a 'petition of concern' concerning a motion, or it is their failure to support a motion which leads to it being vetoed.

73 F Ní Aoláin, 'Political Violence and Gender During Times of Transition' (2006) 15(3) Columbia Journal of Gender and Law 829, 840.

74 Acronyms used in this report included people who identify as intersex.

75 S Dane, L Short and G Healy, Swimming with Sharks: The Negative Social and Psychological Impacts of Ireland's Marriage Equality Referendum No' Campaign (School of Psychology Publications, University of Queensland, Australia 2016) http://espace.library.uq.edu.au/view/UQ:408120.

76 Ibid 7.

77 Hayes and Nagle (n 41) demonstrate how ethno-nationalist groups in societies such as Northern Ireland 'may also seek to co-opt the language of gay and lesbian rights as a means to advance their own political platforms as liberal and progressive in distinction to their ethnonational rivals, who are framed as conservative and reactionary': 24.

78 Following the most recent dissolution of the Northern Ireland Assembly, marriage equality became central to the negotiations for the formation of the new Executive. 
rights. ${ }^{79}$ Such debate was in plentiful supply following a request made to a bakery for cake to form part of promotional materials calling for equal marriage. ${ }^{80}$ The cake was to feature Sesame Street characters Bert and Ernie, along with a message saying 'Support gay marriage' and the logo of a local LGB\&T organisation. Asher's bakery initially accepted the order, but subsequently refused to complete the request a little while later. The Equality Commission duly brought a case for sexual orientation discrimination under the Equality Act (Sexual Orientation) Regulations (Northern Ireland) 2006, SI 436/2006, which it won. The failure of Asher's Bakery in Belfast to provide the service on the basis that it was against the proprietors' religious beliefs was deemed unlawful by the court. The case later prompted DUP politician Paul Givan to propose a Freedom of Conscience Amendment Bill to allow exemptions to the Equality Act on religious grounds. The proposed amendment sought to undermine equality, instigating a two-tier system with regards to prioritising appropriated doctrinal beliefs over embodied identity characteristics. No efforts were made by the DUP to engage with the Northern Ireland LGB\&T sector in the lead-up to the draft consultation on the amendment. LGB\&T advocacy groups indicated the biased and leading nature of the questions on the consultancy document, the lack of initial engagement with Northern Irish LGB\&T groups and the lack of evidence for the multiple inferences made in the consultation document as to the strength of negative lay feeling towards sexual minorities in Northern Ireland. ${ }^{81}$

In fact, evidence exists to the contrary; attitudes towards LGB\&T identities are improving according to the Northern Ireland Life and Times (NILT) survey. The study asks a selection of questions on social, political and religious issues; in recent years, an increasing number of these questions have focused on issues relating to homosexuality, the findings from which demonstrate significant improvements in responses to LGB\&T issues. One question asks about whether sexual relations between adults of the same sex is in any way 'wrong'. In 1998 when this question was first asked, over half (58\%) of respondents indicated that it was 'always wrong'; this reduced to $44 \%$ in 2004 and 2008, but had fallen to just over a quarter $(27 \%)$ in 2013 . Over the same period of time, the number of respondents indicating that sexual relations between two adults of the same sex is 'not wrong at all' had increased from $15 \%$ in 1998 to $24 \%$ in 2008 , before doubling to $43 \%$ in $2013 .{ }^{82}$ Questions asked in 2013 included those relating to family dynamics, such as whether lesbians should be allowed equal access to IVF treatments as enjoyed by heterosexual women, whether lesbians or gays should be allowed to adopt, and whether lesbians or gays with children count as a 'family'. 83 The results indicated positive approaches, with $50 \%$ of respondents believing that lesbian women ought to have equal access to IVF (37\% opposed); a slight majority approving of the adoption of children by couples who are gay (40\% for, 33\% against) or lesbian ( $45 \%$ for, $28 \%$ against); and twice as many respondents agreeing with the statement that a lesbian couple with a child or a gay couple with a child counts as a 'family' (64\% for, $32 \%$ against and $62 \%$ for, $34 \%$ against respectively). Positive attitudes were also demonstrated in the responses given for questions about teaching about LGB\&T equality in schools (58\% for, 31\% against) and

79 Ashe (n 46) 25.

80 For a timeline review of this case, see the BBC's resource "'Gay Cake" Case Key Dates $<$ www.bbc.co.uk/news/av/uk-northern-ireland-37753930/gay-cake-case-key-dates>.

81 Ultimately, the NIHRC indicated that the proposed 'freedom of conscience' exception would be incompatible with the ECHR on several grounds and, as a result, rendered the amendment outside the legislative competence of the Northern Ireland Assembly under the Northern Ireland Act 1998.

82 Northern Ireland Life and Times Survey <www.ark.ac.uk/nilt>. Question topics vary each year; 2013 was the most recent year in which LGB\&T questions were included.

83 Ibid. 
recognising same-sex marriages (59\% for, 29\% against). In sum, acceptance of LGB\&T sexualities, rights and families has increased significantly in Northern Ireland; yet, in spite of this evidence, several prominent politicians, particularly those affiliated to the DUP and with a significant public profile, remain steadfastly opposed to enhancing the sociolegal rights of LGB\&T citizens in Northern Ireland.

In 2011, changes to blood donation rules enacted in England, Wales and Scotland replaced the lifetime ban on gay and bisexual male donors with a 12-month deferral (and abstinence) period. ${ }^{84}$ This permits donations if conditions are met, however, a review is currently underway to assess whether this deferral period should be abolished. ${ }^{85}$ In Northern Ireland, the failure to adopt a similar position towards donors was justified by former Northern Ireland Health Minister Edwin Poots (when in post) as being based on prioritising the rights of people to receive 'safe' blood over the right of people who are deemed 'risky' to donate. ${ }^{86} \mathrm{In}$ his statements, the minister claimed that his decision to retain the lifetime ban in Northern Ireland was not just aimed at gay men, but at those who have had sex with someone in Africa or with a prostitute. Following judicial review, Poots was ruled to have acted in an 'irrational and unlawful' way by the High Court judge, who also highlighted the apparent bias which must be involved given that Northern Ireland accepts blood from the rest of the UK which could have been donated by gay and bisexual men. ${ }^{87}$ However, the Court of Appeal in Belfast later dismissed this ruling and determined that the decision was to be made by Stormont's Health Minister. ${ }^{88}$

Poots' successor was DUP MLA Jim Wells, who had supported his predecessor's position on the blood ban issue, but only managed to remain in post for six months. In the lead-up to the 2015 general election, Wells took part in an election debate following which a short recording appeared to show him making the following comments:

All evidence throughout the world says the best way to raise children is in a loving, stable, married relationship; the facts show that, the facts show that certainly you don't bring a child up in a homosexual relationship. That a child is far more likely to be abused or neglected. I say again, I say again, a child is far more likely to be abused or neglected in a non-stable marriage situation, gay or straight. ${ }^{89}$

Allegations of homophobia directed at Mr Wells were fuelled by a second incident which had taken place just two days after the election debate, where he allegedly made critical remarks to a lesbian couple about their 'lifestyle' whilst canvassing their doorstep. ${ }^{90} \mathrm{Mr}$

84 Department of Health (Press Release 2011) <www.gov.uk/government/news/lifetime-blood-donation-banlifted-for-men-who-have-had-sex-with-men $>$.

85 P Predergast, 'Government to Review 12-month Deferral Period for Gay Men Donating Blood' BBC Newsbeat (14 June 2016) <www.bbc.co.uk/newsbeat/article/36531235/government-to-review-12-month-deferralperiod-for-gay-men-donating-blood $>$.

86 'Poots Sticks to his Guns over Gay Blood Ban' Newsletter (18 June 2012) <www.newsletter.co.uk/news/pootssticks-to-his-guns-over-gay-blood-ban-1-3962846>.

87 'Gay Blood Ban “Irrational”, Judge Rules' BBC News (11 October 2013) <www.bbc.co.uk/news/uk-northernireland-24494371>.

88 [2016] NICA 20. In keeping with this ruling, the ban was finally lifted by Sinn Féin's Michelle O’Neill in September 2016 with the agreement of all parties in the Executive.

89 M Fealty, 'How We Got Jim Wells Wrong, Twitter Rage and the Redaction of Empathy . . .' $<$ http://sluggerotoole.com/2015/10/20/how-we-got-jim-wells-wrong-twitter-rage-and-the-redaction-ofempathy; the recording can also be viewed at www.youtube.com/watch?v=exHnnSNLVMY>.

90 H McDonald and D Gayle, 'Jim Wells Resigns as Northern Ireland Health Minister over "Anti-gay" Remarks' The Guardian (London, 27 April 2017) <www.theguardian.com/uk-news/2015/apr/27/jim-wells-resignsnorthern-ireland-health-minister>. 
Wells resigned as Health Minister shortly after these events, citing his wife's ill-health as the catalyst for his decision. Meanwhile, a six-month Public Prosecution Service investigation into whether or not he had breached Article 9 of the Public Order (NI) Order 1987, SI 463/1987, during the election debate concluded that there was insufficient evidence to pursue a prosecution, based upon its review of a longer transcript of his comments. ${ }^{91}$

Harmful, moralistic perspectives in relation to homosexuality and parenting have fuelled discrimination towards lesbian and gay citizens' access to adoption rights in Northern Ireland. The Employment (Northern Ireland) Order 2002 bestows same-sex parents in Northern Ireland with rights as individuals in relation to adoptive/parental leave and flexible working. Families are further protected by the Civil Partnership Act 2004, which created a new legal status that allows adult same-sex couples to gain formal recognition of their relationship. Available data indicates an average of 100 ceremonies taking place annually in Northern Ireland since registration became available in 2006. ${ }^{92}$ Approximately 2000 people from the LGB\&T population in Northern Ireland are, or have been, in a civil partnership 93 over the last decade. However, until a judicial review decision in 2013, civil partners were unable to adopt as a couple due to a purposeful failure to amend existing adoption legislation to recognise and include civil partners as applicants. Article 15 of the Adoption (Northern Ireland) Order 1987, SI 2203/ 1987, as amended by the Civil Partnership Act 2004, stated that a person who is 'not married or a civil partner' can adopt as a single person, whereas Article 14 (which was not initially amended) stated that only married people can adopt as a couple. This double exclusion of civil partners was initially perceived by many to have been a mistake or oversight. During the judicial review, however, it emerged that Northern Ireland's Health Department had actually intended to ensure the restriction and that it was not in fact a mistake.

In their assessment of court decisions in human rights cases in Northern Ireland, Dickson and McCleave suggests that there is 'scope for further judicial activism in developing the common law in a way which brings it more into line with the UK's human rights obligations at the international level'. ${ }^{94}$ The above highlighted case studies indicate the complexities involved for members of LGB\&T communities seeking protection or the enforcement of rights as they must necessarily engage with what has historically been a persecutory legal domain. These cases, and the political rhetoric linked to them, provide useful evidence as to the factors informing and sustaining homophobia in Northern Ireland. As Kinsman ${ }^{95}$ suggests, 'examining historical experiences and practices can help us understand from where lesbian and gay oppression and, more generally, oppressive sexual regulation has come, where it may be going, and the possibilities for transformation'. Yet legal recourse has been a necessary last resort for effecting change; in contrast, enlisting the input of minorities at policy-drafting level in order to promote

91 D McAleese, 'DUP's Jim Wells Eyes Comeback after Gay Slur case is Thrown Out' Belfast Telegraph (Belfast, 17 October 2015) <www.belfasttelegraph.co.uk/news/northern-ireland/dups-jim-wells-eyes-comeback-aftergay-slur-case-is-thrown-out-34116962.html>.

92 Northern Ireland Statistics and Research Agency (2014) Marriages, Divorces and Civil Partnerships in Northern Ireland $2013<$ www.gov.uk/government/statistics/marriages-divorces-and-civil-partnerships-in-northernireland-2013>.

93 The agency also documents the marital status of civil partnership registrants, indicating a trend exists whereby most applicants are single although a minority have previously been in a heterosexual marriage or a prior civil partnership.

94 B Dickson and T McCleave, 'Human Rights in the Courts of Northern Ireland 2009-10' (2010) 61(4) Northern Ireland Legal Quarterly 411, 429.

95 G Kinsman, The Regulation of Desire: Homo and Hetero Sexualities (Black Rose Books 1996) 25. 
equality among a diverse range of identities demonstrates an alternative way of enabling integration, equality and inclusion.

\section{Redefining 'integration'}

Section 75(2) of the Northern Ireland Act 1998 outlines public bodies' responsibilities to have 'due regard' to provide equality of opportunity across all nine groups identified under s $75(1)^{96}$ and to promote 'good relations' between these different persons. Therefore, it compels the statutory sector to engage with LGB\&T advocates and organisations on issues relating to the effective implementation of duties. During their drafting of the 'Cohesion, Sharing and Integration' (CSI) document, ${ }^{97}$ the Office of the First Minister and Deputy First Minister (OFMdFM) underwent a series of community consultations in line with its obligations under s 75(2). However, it later emerged from LGB\&T organisations that the government's original intention was not to consult with the wider LGB\&T community or its representatives, yet, having done so, still managed to produce a draft document with glaring omission of considerations specific to LGB\&T community members. ${ }^{98}$ Advocates' concerns suggested that this was indicative of some politicians' failure to recognise or acknowledge either the presence of LGB\&T people during the conflict or the impact of this experience on exacerbating their minority status:

By excluding the representations made by the LGBT community throughout the process of drafting CSI, OFMdFM has only served to perpetuate the existing discrimination and disadvantage our community faces . . OFMdFM has blatantly ignored the plethora of research repeatedly identifying the marginalisation of lesbian and bisexual women and their families, within social, economic, political and geographical structures. ${ }^{99}$

The omission of reference to LGB\&T communities in particular areas of the document - such as its aims for empowering the next generation; respecting cultures; and building secure and cohesive communities - not only indicated a hierarchy of prejudice in terms of whose identity or experience is prioritised, but also a failure to see how LGB\&T issues need to be situated within wider social, political, health and economic strategies to effect real and lasting change. The NIHRC indicated that the draft document made no direct reference to binding human rights standards, leading to several organisations calling for the finalised version to be underpinned by these. The CSI consultation made reference to targeted victimisation and hate incidents, but only explicitly to those of a sectarian and racist nature. The omission of trans* issues in both the initial s 75 equality policies and the CSI consultation document ignored and invalidated the needs of transgender people in Northern Ireland. Discrepancies with England and Wales are evident here too, as 'gender identity' is not recognised as a protected hate crime characteristic in Northern Ireland. ${ }^{100}$ Although the Police Service of Northern Ireland has documented trans*

96 These are: religion, political opinion, gender, disability, race, ethnicity, sexual orientation, marital status and dependency.

97 See http://cain.ulst.ac.uk/issues/politics/ofmdfm/ofmdfm_270710_sharing.pdf.

98 See the response from the Lesbian Advocacy Services Initiative (LASI) (CSI/215/2010). The response from Queerspace also noted that a reference to LGB\&T groups was made in an earlier draft, but omitted when the final document was put out to public consultation (CSI/126/2010) 7. Contact the author for copies or see the results of the consultation action plan for a round-up of key contributors and their points <http://www.niassembly.gov.uk/globalassets/documents/corporate/commission/good-relations-actionplan-2010-11.pdf $>$.

99 See LASI (n 98) 3.

100 In England and Wales, the Legal Aid, Sentencing and Punishment of Offenders Act 2012 outlined provisions for gender identity to be recognised as a 'hate crime' category. 
experiences of victimisation since 2006, no specific legal remedy exists to recognise the transphobic element in a prosecution or conviction, unlike crimes based on a perpetrator's hostility towards race, religion, sectarianism, sexual orientation and disability (which are legally recognised). ${ }^{101}$

In an attempt to respond to these criticisms, the CSI document outlined a commitment by the OFMdFM to produce a dedicated Sexual Orientation Strategy. On the one hand, this indicated a positive move, recognising the existence of sexual minorities as a distinct social group and the need for targeted decisions which reflected their requests. On the other, the separating out of sexual orientation issues suggested to some that the issues affecting sexual minorities were not perceived as relevant to the wider society, thus undermining the very nature of 'cohesion' and 'integration'. Previous attempts to enact a Sexual Orientation Strategy in 2006 had failed to come to fruition despite consultations occurring with relevant LGB\&T advocacy organisations, thus the prioritising of such a venture was deemed questionable by those representing their communities' interests. LGB\&T advocates indicated that outlining definitive publication dates for the strategy would go some way to restoring faith in both the project and the sentiment behind its establishment, whilst also directing ministers to Principle 26 of the Yogyakarta Principles which calls on signatory states to:

a) Take all necessary legislative, administrative and other measures to ensure opportunities for the participation in cultural life of all persons, regardless of, and with full respect for, their sexual orientations and gender identities; and

b) Foster dialogue between, and mutual respect among, proponents of the various cultural groups present within the State, including among groups that hold different views on matters of sexual orientation and gender identity, consistently with respect for the human rights referred to in these Principles. ${ }^{102}$

The OFMdFM finally put out for consultation a Sexual Orientation Strategy and Action Plan in 2014. The consultation document recognised the problems LGB\&T people face due to prejudice and intolerance and acknowledged that good relations principles must apply to LGB\&T people in the same way that they apply to people from different religious, community or ethnic backgrounds:

Lesbian, gay, bisexual and transgender people have and do play a role in building good relations across our community. This was highlighted extensively throughout the public consultation when a number of individuals and representatives of lesbian, gay and bisexual groups, and transgender people, also spoke of the need to apply good relations principles more widely across all s 75 groupings. 103

The report compiled from the 995 responses to the consultation indicated strong support for all five of the proposed objectives, namely:

- Countering homophobia, including homophobic harassment, hate crime, bullying, violence and abuse.

101 U Hansson and H Depret, Equality Mainstreaming: Policy and Practice for Transgender People (Institute for Conflict Research 2007).

102 See <www.yogyakartaprinciples.org/principle-26>.

103 OFMdFM, 'Development of a Sexual Orientation Strategy and Action Plan' (OFMdFM 2014) $<$ www.communities-ni.gov.uk/sites/default/files/consultations/ofmdfm_dev/developing-a-sexualorientation-strategy-consultation-document.pdf $>1.4$. 
- Adopting a positive and proactive approach to identifying, understanding and responding to the needs of LGB people and their families.

- Ensuring that negative stereotypes of LGB people and homophobia have no place in policy development or decision-making.

- Recognising the multiple identities of LGB people (e.g. gender identity, ethnic origin, disability, occupation) as well as the impact of these other identities on individual circumstances.

- Promoting a partnership approach to delivering effective and inclusive policies and service delivery, enabling departments, agencies, statutory bodies, NGOs, trade unions, and voluntary and community groups to work productively together and share best practice. ${ }^{104}$

Other issues raised within the scope of the study included a need to recognise the diversity of lesbian, gay and bisexual family units, ${ }^{105}$ greater accountability among political representatives, as well as the separation of personal views from policy decisions. ${ }^{106}$ Also included in the report were responses suggesting the inclusion of heterosexual people, and that such a strategy was unnecessary; these were considered outside of the scope of the consultation. The report concluded by indicating that all consultation responses and research findings would be taken into account in the development of a draft Sexual Orientation Strategy, which, if agreed upon by ministers of the Executive, would be put out for a further 12-week online consultation process. ${ }^{107}$

It would seem therefore that the political agency afforded to LGB\&T communities in Northern Ireland has been a necessary result of transformative social, structural and statutory change, but one that is significantly shaped by Northern Ireland's socio-political past. Recognition of this is only just beginning to emerge as an area of scholarly focus, leaving plenty of scope for analysis with respect to understanding the relationship between sexual minority status and transitional justice in Northern Ireland. This dearth suggests that there is still some way to go to fully integrate LGB\&T communities in transformative practices in the region, as Ashe outlines:

Mainstream conflict transformation scholarship has not considered the effects of legal frameworks on sexual equality but has extensively scrutinised legislation on ethnic equality. It has, therefore, failed to provide a research base for sexual politics in Northern Ireland. ${ }^{108}$

This could change, however, with the growing recognition of sexual minority groups and the necessary intersections between sexual identity and religion and ethnicity and nationality in Northern Ireland. Also, given the victimised status of LGB\&T communities when it comes to effecting rights and equalities (as detailed above), recognising that victimisation may be heightened as a result of one or more of these variables renders this a valid area for study. Given the nature of Northern Ireland, how this is addressed will have a great bearing on outcome. Just addressing sexual orientation without other identity factors could result in the marginalising or essentialising of groups and/or experiences.

104 OFMdFM, 'Report on Consultation to Develop a Sexual Orientation Strategy' (OFMdFM 2015) <www.communities-ni.gov.uk/sites/default/files/publications/ofmdfm/sexual-orientation-strategyconsultation-report.pdf $>$ at 1.19 .

105 Ibid 1.11.

106 Ibid 1.13 .

107 At the time of writing, this follow-up work was still ongoing with no draft Sexual Orientation Strategy document yet released.

108 Ashe (n 46) 26. 
As Fobear suggests, an 'essentializing of narrative and confining identity in a fixed construction not only limits critical analysis of the underlying social structures that allow violence to happen in both the past and the present, but also denies the diversity and plurality of experience'. ${ }^{109}$ Certainly in Northern Ireland, there is adequate scope for exploring the heterogeneity of LGB\&T experiences and to 'queer' dominant discourses from a position of inclusion.

\section{Conclusion: queering transitional justice in Northern Ireland}

Bell and O'Rourke ${ }^{110}$ have addressed feminist concerns regarding exactly what it is that transitional justice is transitioning 'from' and 'to', indicating how 'ordinary, liberalising and restorative' theories of justice underpin transitional perspectives. In the first, ordinary, comparisons with existing justice measures account for the similarly partial nature of transitional justice, where a 'justice gap' will also feature and require toleration. The second perspective, liberalising, also addresses (and allows for) this gap in light of the ultimate goals to be achieved through transition, viewing the rule of law as a limited yet transformative and enabling process. Finally, the restorative perspective rejects accountability and legal routes for restoration and reparation of relationships and communities. Which of these approaches prove most useful largely depends on the wishes of the citizens living there, but it is important to note that in transformative societies, these spaces open up.

This paper has demonstrated how, in Northern Ireland, processes of transformation have made space to invoke queer and intersectionality theories, providing a useful framework within which to account for multiple identity factors informing and sustaining socio-legal inequalities. ${ }^{111}$ Applying queer theoretical analysis enables a better understanding of the origins and developments of dominant identity constructions framing minority sexualities in such negative discourses. ${ }^{112}$ Adding intersectionality theory facilitates an analysis of 'the masculinity of conflicts and the dominance of elite men, who are key influencers in state institutions empowered to enforce or impede enforcement of negotiated terms'. ${ }^{113}$ Both inform a critical sexual analysis of transitional justice mechanisms, which in turn allows for a greater recognition of harms imparted that may otherwise remain visible under a dominant heteronormative framework of analysis, as McEvoy notes:

A further consideration of the impact of sexuality on the study of post-conflict studies is the way that LGBT identities undermine the peacebuilding processes of wartorn communities... We could imagine the increased feelings of isolation that LGBT people might feel in a context in which collective community building efforts are predicated on a highly heteronormative script. ${ }^{114}$

The transitional justice literature indicates that the emergence of truth commissions as a popular approach is due to the acknowledgment of marginalised experiences: giving space

109 Fobear (n 35) 10.

110 C Bell and C O'Rourke, 'Does Feminism Need a Theory of Transitional Justice? An Introductory Essay' (2007) 1 International Journal of Transitional Justice 23-44.

111 Fobear (n 35)

112 A Jagose, Queer Theory (Melbourne University Press 1996).

113 F Ní Aoláin and E Rooney, 'Under-enforcement and Intersectionality: Gendered Aspects of Transition for Women’ (2007) 1 International Journal of Transitional Justice 338, 340.

114 S McEvoy, 'Queering Security Studies in Northern Ireland: Problem, Practice and Practitioner' in M Lavinas Picq and M Thiel (eds), Sexualities in World Politics: How LGBTQ Claims Shape International Relations (Routledge 2015) 146. 
and priority to otherwise suppressed voices. As Fobear ${ }^{115}$ suggests, queer theory can act as 'a much needed addition not only to truth commissions, but to research and advocacy related to transitional justice mechanisms' due to queer theory's inherently critical and critiquing nature of power relations and imposed social structures. Appropriating this tool to showcase the struggles faced by members of LGB\&T communities in Northern Ireland would therefore be an appropriate starting point from which to develop a culturally specific 'history of sexuality' in the region. It would also offer a much needed counter-narrative to the dominant doctrinal and political discourses of public condemnation which still characterise much of the rhetoric around LGB\&T identities in Northern Ireland. It is important that sexual minority voices, which may be silenced through fear of additional prejudice and persecution, are safely included to ensure that accountability processes embody inclusivity, impartiality and integrity. Transitional justice has demonstrated the potential for effective and inclusive mechanisms of conflict transformation, but for Northern Ireland to truly move beyond its 'politics of the past' it must acknowledge and document the lived experiences of its LGB\&T citizens before the opportunity to do so is lost. 